\title{
Therapeutic plasma exchange (TPE) treatment in COVID-19 related Multisystem inflammatory syndrome in children (MIS-C) who admitted with acute abdomen clinic
}

\author{
Mücahit Oğuz Kağan Türk, ${ }^{1}$ (D) Canan Hasbal Akkuş, ${ }^{1}$ () Gürkan Atay, ${ }^{2}$ () Seher Erdoğan, ${ }^{2}$ \\ Deniz Çakır, ${ }^{3}$ (1) Enes Salı, ${ }^{3}$ (1) Betül Sözeri ${ }^{4}$
}

${ }^{1}$ Department of Pediatriy, University of Health Sciences, Ümraniye Training and Research Hospital, İstanbul, Turkey ${ }^{2}$ Department of Pediatric Intensive Care Unit, University of Health Sciences, Ümraniye Training and Research Hospital, İstanbul, Turkey ${ }^{3}$ Department of Pediatric Infectious Diseases, University of Health Sciences, Ümraniye Training and Research Hospital, İstanbul, Turkey ${ }^{4}$ Department of Pediatric Rheumatology, University of Health Sciences, Ümraniye Training and Research Hospital, İstanbul, Turkey

\section{ABSTRACT}

In March 2020, the World Health Organization designated the disease Coronavirus Disease 2019 (COVID-19), which caused by Severe Acute Respiratory Syndrome-Coronavirus-2 (SARS-CoV-2), as a pandemic. Prognosis of the disease proceed generally mildly in pediatric cases. Rarely, children have been affected severely and prognosis can be different from adult patients. Since May 2020, reports from different countries documented a presentation in children and this condition has been termed as multisystem inflammatory syndrome in children. This report, we presented an 8-year-old patient who was admitted to the hospital with complaints of fever and abdominal pain, was operated by a pediatric surgeon with the diagnosis of acute appendicitis, was followed up with the multisystemic inflammatory syndrome clinic in pediatric intensive care unit, and received intravenous immunoglobulin, steroid, plasmapheresis treatments and inotropic support. This report, we wanted to emphasize that in the COVID-19 pandemic, there may be hospital applications with different clinical presentations in the childhood age group, and the use of intravenous immunoglobulin and plasmapheresis treatment combination can be a life-saving option, especially in multisystem inflammatory syndrome in children cases requiring intensive care.

Keywords: COVID-19; multisystem inflammatory syndrom; plasmapheresis.

Cite this article as: Kağan Türk MO, Hasbal Akkuş C, Atay G, Erdoğan S, Çakır D, Salı E. Therapeutic plasma exchange (TPE) treatment in COVID-19 related Multisystem inflammatory syndrome in children (MIS-C) who admitted with acute abdomen clinic. Jour Umraniye Pediatr 2021;1(1):14-19.

\section{ORCID ID}

M.O.K.T.: 0000-0002-3684-0509; C.H.A.: 0000-0002-2432-2499; G.A.: 0000-0002-0317-5872; S.E.: 0000-0002-3393-3363;

D.Ç.: 0000-0002-7056-0615; E.S.: 0000-0002-8136-1240; B.S.: 0000-0002-5079-5644

${ }^{1}$ Sağlık Bilimleri Üniversitesi Ümraniye Eğitim ve Araştırma Hastanesi, Çocuk Sağlığı ve Hastalıkları Kliniği, İstanbul, Türkiye ${ }^{2}$ Sağlık Bilimleri Üniversitesi Ümraniye Eğitim ve Araştırma Hastanesi, Çocuk Yoğun Bakım Kliniği, İstanbul, Türkiye

${ }^{3}$ Sağlık Bilimleri Üniversitesi Ümraniye Eğitim ve Araştırma Hastanesi, Çocuk Enfeksiyon Hastalıkları Kliniği, İstanbul, Türkiye

${ }^{4}$ Sağlık Bilimleri Üniversitesi Ümraniye Eğitim ve Araştırma Hastanesi, Çocuk Romatoloji Kliniği, İstanbul, Türkiye

Received (Başvuru tarihi): 20.11.2020 Accepted (Kabul tarihi): 25.12.2020 Online (Online yayınlanma tarihi): 15.01.2021

Correspondence (iletişim): Dr. Mücahit Oğuz Kağan Türk. Sağlık Bilimleri Üniversitesi, Ümraniye Eğitim ve Araştırma Hastanesi,

Çocuk Sağlığı ve Hastalıkları Kliniği, İstanbul, Türkiye.

Phone (Tel): +90 5423394010 e-mail (e-posta): mucahitturk_@hotmail.com

(c) Copyright 2021 by Istanbul Provincial Directorate of Health - Available online at www.umraniyepediatri.com 


\title{
Akut batın kliniği ile başvuran COVID-19 ilişkili pediatrik multisistemik inflamatuvar sendrom (MIS-C) olgusunda plazmaferez tedavi etkinliği
}

\begin{abstract}
ÖZET
Etkeni "Severe Acute Respiratory Syndrome-Coronavirus-2 (SARS-CoV-2)" olarak isimlendirilen "Coronavirus Disease 2019 (COVID-19)" 11 Mart 2020 tarihinde Dünya Sağlık Örgütü tarafindan salgın olarak ilan edilmiştir. Çocuklarda COVID-19 genellikle hafiftir. Nadir durumlarda çocuklar ciddi şekilde etkilenebilir ve klinik yetişkinlerden farklı olabilir. 2020 yılı mayıs ayından itibaren dünyanın çeşitli bölgelerinden çocuk olgular rapor edilmiş ve Dünya Sağlık Örgütü bu olguları pediatrik multisistemik inflamatuvar sendrom olarak tanımlamıştır. Bu yazıda, sekiz yaşında, ateş ve karın ağrısı yakınmaları ile hastaneye başvuran, akut apandisit tanısı ile çocuk cerrahi tarafindan opere edilen, multisistemik inflamatuvar sendrom kliniği ile çocuk yoğun bakım ünitesinde izlenerek intravenöz immünglobulin, steroid, plazmaferez tedavileri ve inotrop destek yapılan bir olgu sunulmuştur. Bu olgu ile COVID-19 pandemisinde çocukluk yaş grubunda farklı klinik prezentasyonlarla hastane başvurusu olabileceği, özellikle yoğun bakım ihtiyacı olan multisistemik inflamatuvar sendrom olgularında intravenöz immünglobulin ve plazmaferez tedavi kombinasyonunun kullanılmasının hayat kurtarıcı bir şeçenek olabileceği vurgulanmak istenmiştir.
\end{abstract}

Anahtar Kelimeler: COVID-19; multisistemik inflamatuvar sendrom; plazmaferez.

\section{GíRiş}

“Coronavirus Disease 2019 (COVID-19)” pandemisi dünya genelinde katastrofik hastalık tablosuna yol açmıştır. Erişkin hastalarda COVID-19 hastalığı yaklaşık ikinci haftada (viral yük azalıp, inflamatuvar sürecin şiddetlendiği dönem) şiddetli çoklu organ hasarına yol açmaktadır. Hastalığın patofizyolojisinde konak doğal ve adaptif immün sisteminde bozuklukların rol oynadığı düşünülmektedir. Buna karşın pediatrik olgularda hastalığın prognozunun ılımlı seyrettiği raporlanmakta idi (1, 2). Nisan 2020 tarihinde Birleşik Krallık'ta birkaç pediatrik olguda inkomplet Kawasaki hastalığı ya da toksik şok sendromu benzeri klinik gidiş (kardiyovasküler şok, ateş ve hiperinflamasyon) raporlanmış, sonrasında tüm dünyada benzeri pediatrik olgular tanımlanmış$\operatorname{tr}$ (3). 14 Mayıs 2020 tarihinde Dünya Sağlık Örgütü (DSÖ) bu olguları pediatrik multisistemik inflamatuvar sendrom (MIS-C) olarak tanımlamıştır (4).

Multisistemik inflamatuvar sendrom, tehlikeli ve potansiyel olarak ölümcül olan "Severe Acute Respiratory Syndrome-Coronavirus-2 (SARS-CoV-2)" ile ilişkili yeni bir pediatrik hastalıktır. Çocuklar tipik olarak COVID-19 enfeksiyonundan 3-4 hafta sonra MIS-C belirtileri/semptomları gösterir ve çoğu hızla şoka ve kardiyorespiratuar yetmezliğe ilerler. MIS-C tanısı konulduğunda çocukların çoğunun SARS-CoV-2'ye karşı antikorları pozitifken polimeraz zincir reaksiyonu (PCR) negatiftir. Erken tanı ve tedavi ile çocukların çoğu hayatta kalacaktır ancak hastalığın tanınması ve akılda tutulması çok önemlidir.

Multisistemik inflamatuvar sendrom geliştiren çocukların \%52'sinde altta yatan herhangi bir hastalık yoktur. En sık görülen komorbiditeler ise obezite ve astımdır. Bu durum hastalığın öngörülmez olduğunu düşündürmektedir. Bazı çocukların MIS-C geliştirmeye neden daha duyarlı olabileceğini anlamak için daha fazla araştırmaya ihtiyaç vardır.

Multisistemik inflamatuvar sendrom olgu tanımı ve tanı kriterleri Tablo 1'de belirtilmiştir (5).
Multisistemik inflamatuvar sendromu olan çocuklarda kardiyak belirtilerin baskınlığı da dikkat çekicidir. Birkaç gün içinde koroner arterlerin anevrizması görülmektedir. MIS-C kardiyak tutulumunun uzun vadeli etkileri şu anda bilinmediğinden yakın takip önemli olacaktır. Kalp tutulumu ve klinik görünümü ile Kawasaki hastalığına benzetilen MIS-C'de bulunan ayırt edici klinik özellikler kusma, ishal ve karın ağrısını içerir. Kawasaki hastalığı, beş yaşın altındaki küçük çocuklarda görülürken, MIS-C'deki ortalama yaş dokuzdur. Bu sendromlar arasındaki örtüşen özellikler ise benzer patofizyolojiyi paylaşabileceklerini ve muhtemelen bu hastaların neden benzer tedavilere yanıt verdiğini açıklamaktadır.

\section{OLGU SUNUMU}

Sekiz yaşındaki erkek hasta, iki gündür olan ateş ve boğaz ağrısı şikayetleri ile hastaneye başvurmuştur. Üst solunum yolu enfeksiyonu tanısı ile antipiretik tedavi verilen hasta iki gün sonra ateşin devam etmesi, karın ağrısı ve kusma şikayetlerinin eklenmesi üzerine çocuk acil servise başvurmuştur. Hastanın fizik muayenesinde; genel durumu düşkün, bilinci açık, dehidrate görünümde, orofarenks hiperemik, solunum sistemi ve kardiyovasküler sistem bulguları doğal izlenmiştir. Batında sağ alt kadranda belirgin hassasiyeti, defans ve rebound bulgusu mevcuttur. Hastanın laboratuvar tetkiklerinde hemogramda beyaz küre: $4240 \mu \mathrm{L} / \mathrm{mL}$ (nötrofil: $3700 \mu \mathrm{L} / \mathrm{mL}$, lenfosit: $440 \mu \mathrm{L} / \mathrm{mL}$ ), trombosit: $91.000 \mu \mathrm{L} / \mathrm{mL}$, C-reaktif protein (CRP): $10.9 \mathrm{mg} / \mathrm{dL}$ ve elektrolit bozukluğu saptanmıştır.

Akut batın ön tanısı ile çocuk cerrahi tarafindan değerlendirilen hasta akut apandisit ön tanısıyla çocuk cerrahi servisine interne edildi ve takibinde opere edildi.

Postoperatif birinci gün çocuk cerrahi servisi takibinde hastanın genel durumunda bozulma olması üzerine pediatri konsültasyonu yapılmıştır. Hasta anamnezi tekrar sorgulandığında babaannesinin 10 gün önce COVID-19 tanısı ile ev izolasyonunda takibe 


\section{Tablo 1. Multisistemik inflamatuvar sendrom (MIS-C) olgu tanımı (5)}

\section{Multisistemik inflamatuvar sendrom (MIS-C) tanı kriterleri}

1. 0-21 yaş arası ve

2. 24 saatten uzun süren, $>38.0^{\circ} \mathrm{C}$ ölçülmüş veya ailenin ateş varlığını bildirimi ve

3. Laboratuvar tetkiklerinde inflamasyon kanıt (en az 2 veya daha fazla kanıt varlığı)

Yüksek CRP

Yüksek sedim

Yüksek fibrinojen

Yüksek prokalsitonin

Yüksek D-dimer

Yüksek ferritin

Yüksek LDH

Yüksek IL-6 seviyesi

Artmış nötrofil sayısı

Lenfopeni

Hipoalbuminemi ve

4. Hastaneye yatış gerektirecek ağır hastalık tablosu ve

5. Çoklu organ sistem tutulumu (en az 2 veya daha fazlasının varlığı)

Kardiyovasküler (şok, yüksek troponin, yüksek BNP, anormal EKO bulguları, aritmi)

Solunum (pnömoni, ARDS, pulmoner emboli)

Böbrek (böbrek yetmezliği)

Nörolojik (konvülziyon, inme, aseptik menenjit)

Hematolojik (koagülopati, yüksek D-dimer düzeyi)

Gastrointestinal (yüksek karaciğer enzimleri, ishal, ileus)

Dermatolojik (eritrodermi, mukozit, diğer döküntü) ve

6. Alternatif başka tanı olmaması (bakteriyel sepsis, enterovirüs enfeksiyonu gibi miyokardit ile ilişkili enfeksiyonlar, stafilokoksik veya streptokoksik toksik şok sendromları gibi) ve

7. Geçirilmiş veya yeni geçirilmekte olan SARS-CoV-2 enfeksiyon kanıt (aşağıdakilerden en az birisinin varlığı)

SARS-CoV-2 RT-PCR pozitifliği

SARS-CoV-2 seroloji pozitifliği

SARS-CoV-2 antijen pozitifliği

Semptomların başlamasından önceki 4 hafta içerisinde SARS-CoV-2 pozitif olgu teması

CRP: C-reaktif protein; LDH: Laktat dehidrogenaz; IL: İnterlökin; BNP: Beyin natriüretik peptid; EKO: Ekokardiyografi; ARDS: Akut solunum sıkıntisı sendromu; SARS-CoV-2: Severe acute respiratory syndrome-coronavirus-2; RT-PCR: Gerçek zamanlı-polimeraz zincir reaksiyonu.

alındığı, izolasyon sürecinde hastanın babaannesi ile temas öyküsü mevcut olduğu öğrenilmiştir. Hastanın genel durumunun kötü olması, hipotansif seyretmesi, solunum sıkıntısının olmaSI, septik tablo gelişmesi üzerine ön planda MIS-C düşünülerek hasta çocuk servisine interne edilmiştir. Sıvı replasman tedavilerine yanıt vermeyen hipotansiyon izlenmesi üzerine inotrop desteği olarak noradrenalin tedavisi başlanmıştır. Vankomisin ve meropenem antibiyoterapileri başlanmıştır. Çocuk romatoloji bölümü tarafindan değerlendirilen hastada ön planda MIS-C düşünülerek intravenöz immünglobulin (IVIG) tedavisi başlanmıştır. Sıvı tedavisine yanıtsız hipotansiyon olması ve takibinde solunum sıkıntısının artması üzerine hasta çocuk yoğun bakım ünitesine transfer edilmiştir.

Yoğun bakım başvurusunda hastanın bilinci açık, genel durumu kötü olarak izlenmiştir. Solunum sistemi muayenesinde takipneik-dispneik (solunum sayısı: 45/dakika) ve oksijen satürasyonu \%93 (oda havasında) izlenmiştir ve solunum seslerinde dinlemekle kaba raller mevcuttur. Kardiyovasküler sistem muayenesinde S1, S2 doğal S3 yok, 2/6 sistolik üfürüm mevcuttur. Inotrop desteği altında kan basıncı $85 / 50$ mmHg ölçülmüştür. Batında hassasiyet mevcuttur. Yüksek akışlı nazal kanül oksijen tedavisi (YANKOT) ile solunum desteğine alınmıştır. Arter kate- 
terize edilerek tansiyon arteriyel takibine alınan hastaya 10 FR hemodiyaliz kateteri femoral venden takılmıştır. İnotrop olarak noradrenalin alan hastanın titrasyonu arter tansiyonuna göre ayarlanmıştır. Tetkiklerinde beyaz küre: $3620 \mu \mathrm{L} / \mathrm{mL}$ (nötrofil: $3130 \mu \mathrm{L} / \mathrm{mL}$, lenfosit: $300 \mu \mathrm{L} / \mathrm{mL}$ ), hemoglobin: $9 \mathrm{~g} / \mathrm{dL}$, hematokrit: \%26.3, trombosit: $68.000 \mu \mathrm{L} / \mathrm{mL}$, akut faz reaktanlarında ve inflamatuvar belirteçlerde artş̧ (CRP: $14.7 \mathrm{mg} / \mathrm{dL}$, ferritin: $2355 \mathrm{~mL} / \mathrm{ng}$, D-dimer: $6987 \mathrm{ng} / \mathrm{mL}$ ) ve hipoalbuminemi (albumin: $2 \mathrm{~g} / \mathrm{L}$ ) saptanmıştır. Hastaya eritrosit süspansiyonu ve albumin replasmanı yapılmıştır.

Kardiyak değerlendirmesinde ekokardiyografide ejeksiyon fraksiyonu: \%68, kısalma fraksiyonu: \%37, triküspit yetmezliği (hafif-orta), mitral yetmezliği (hafif) izlenmiştir. Perikardiyal efüzyon saptanmamış, sağda $9 \mathrm{~mm}$, solda $6 \mathrm{~mm}$ plevral efüzyon saptanmıştır. Hastanın hipotansiyonu kontrol altına alınarak hem inotropik hem de vazodilatör etkisi nedeniyle milrinon infüzyonu başlanmıştır.

Çocuk romatoloji bölümünün önerisiyle taze donmuş plazma ile plazmaferez tedavisi ivedilikle uygulanmıştır. Deksametazon tedavisi $0.6 \mathrm{mg} / \mathrm{kg} /$ gün olarak başlanmıştır. IVIG tedavisi $1 \mathrm{~g} /$ kg/gün iki gün uygulanmıştr. Rektal kanama öyküsü nedeniyle antiagregan tedavi düşünülmemiştir.

Toraks bilgisayarlı tomografide plevral efüzyon saptanan hastaya girişimsel radyoloji tarafindan ultrasonografi eşliğinde torasentez yapılmış ve toraks tüpü yerleştirilmiştir. Hastamızın akciğer grafisi ve toraks bilgisayarlı tomografi görüntüleri Şekil 1'de gösterilmiştir. Plevra sıvı örneği transüda özellikte izlenmiştir. Plevra kültürü ve aside dirençli basil/mikobakteri incelemesinde üreme olmamıştır. Drenaj ihtiyacı olmayınca yedinci günde toraks tüpü çıkarılmıştır.

Hastadan nazofaringeal sürüntüden çalışılan ardışık üç COVID PCR testi negatif saptanmasına karşın; COVID antikor pozitif (COVID IgM: Negatif/COVID IgG: Pozitif) saptanmıştır.

Takibinde klinik bulgularda iyileşme izlenmiştir. Laboratuvar değerleri düzelmiştir. Ekokardiyografide mitral ve triküspit yetmezlikte gerileme izlenmiştir. Alt seans plazmaferez yapılmış ve altı gün süreyle inotrop destek verilmiştir. İki doz IVIG verilmiştir. Hasta dekort ve antibiyoterapiye devam edilerek servise interne edilmiş ve 14. günün sonunda iyilik hali ile taburcu edilmiştir.

\section{TARTIŞMA}

Multisistemik inflamatuvar sendrom patofizyolojisinde konak doğal ve adaptif immün sisteminde bozuklukların rol oynadığı düşünülmektedir. Kawasaki hastalığı, makrofaj aktivasyon sendromu, sitokin salınım sendromuna benzer şekilde virüse karşı oluşan anormal immün yanıt rol oynamaktadır (6). Kardiyak etkilenimin mekanizması net tanımlanamamış olsa da sistemik inflamasyon, akut viral miyokardit, hipoksi, stres kardiyomiyopatisi ve nadiren koroner arter iskemisi ile ilişkili olduğu düşünülmektedir (7).

Yirmi bir yaşın altında laboratuvar sonucuyla konfirme edilmiş COVID-19 hastalığı sıklığı 32/100.000 olarak saptanırken; MIS-C sendromu yaklaşık 2/100.000 sıklıkta rastlanmaktadır (8). Çoğu

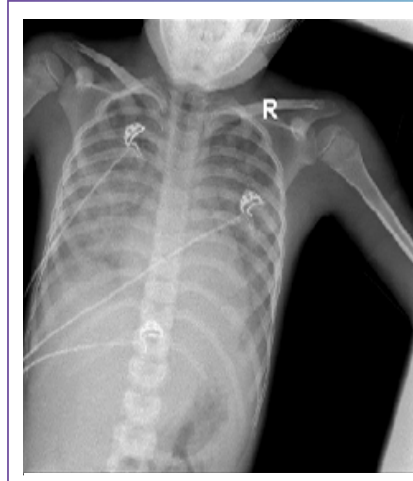

Toraks bilgisayarlı tomografi (07.10.2020): Bilateral akciğerlerde yaygın alveoler dolumlar gelişmiş olup akciğer ödemi açısından klinik bilgilerle değerlendirilmesi önerilir. Bilateral belirgin plevral efüzyonlar mevcuttur. Konjesyon bulgularının ileri derecede gürültülü görünümü nedeniyle viral infiltrasyon açısından değerlendirme yapılamamıştır.
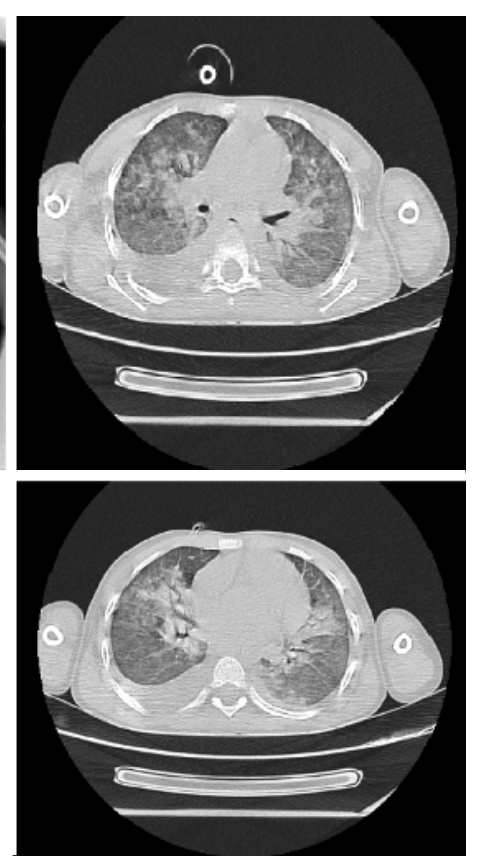

Şekil 1. Ön-arka akciğer grafisi ve toraks bilgisayarlı tomografisi.

pediatrik hastada COVID PCR negatif saptanmasına karşın antikor serolojisi pozitif saptanmaktadır. Bu durum MIS-C'nin akut enfeksiyon süreci geçtikten sonra immün sistemdeki bu sürece bağlı disregülasyonla ilişkili olduğu fikrini güçlendirmektedir. Buna karşın bazı olgularda COVID PCR ve antikor seroloji çalışmalarının her ikisi de pozitif ya da daha az sıklıkta her ikisi de negatif saptanabilmektedir $(8,9)$.

COVID-19 ilişkili pediatrik MIS-C tanılı olguların izleminde hiperinflamatuvar sürecin gerilemesine yönelik geniş kapsamlı tedavi algoritması uygulanmaktadır. Geniş spektrumlu antibiyotik tedavisi düzenlenmesi, kardiyak tutuluma yönelik hemodinamik stabiliteyi sağlamak amacıyla inotrop desteği ve sıvı resüsitasyonu sağlanması, Kawasaki benzeri bulgularla ilerleyen olgularda IVIG, intravenöz kortikosteroid ve asetilsalisilik asit verilmesi önerilmektedir. Ekstrakorporeal tedavi yöntemlerine değinilmesine rağmen literatür taramasında uygulanan olgulara rastlanmamıştır. Bu olgunun sunulmasının amacı, IVIG ve terapötik plazma değişimi (TPD) tedavi kombinasyonunun uygulanmış olması ve etkinliğinin yüz güldürücü olmasıdır.

Pediatrik multisistemik inflamatuvar sendrom olgularının genellikle üst solunum yolu enfeksiyonu benzeri bulgularla seyrettiği görülmektedir. Ek olarak bulant, kusma, karın ağrısı, ishal gibi gastrointestinal sistem bulguları da eşlik etmektedir. Ahmed ve arkadaşlarının çalışmasında karın ağrısı şikayetinin olgularda belirgin izlendiği; Bel-hadjer ve arkadaşlarının çalışmasında bazı olguların akut batın nedeniyle opere edildiği ancak sonrasında bunların mezenter lenfadenit olarak tespit edildiği görülmektedir $(10,11)$. Radia ve arkadaşları da olguların \%71 gastrointestinal sistem bulgularıyla başvurduğunu raporlamışlardır (12). Bizim çalışmamızda da literatürdekilere 


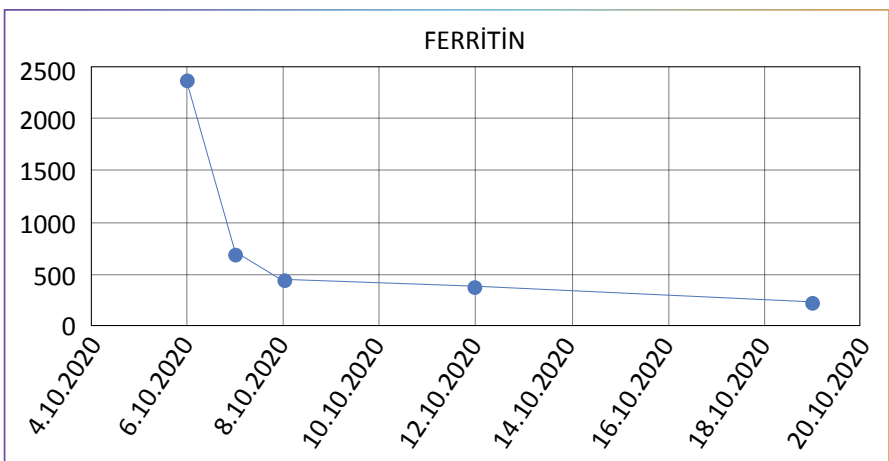

Şekil 2. Terapötik plazma değişimi (TPD) öncesi ve sonrası ferritin düzeyi takibi.

benzer şekilde olgu akut apandisit ön tanısıyla opere edilmiş, sonrasında MIS-C tanısı almıştır. Bu açıdan karın ağrısı, kusma, ishal gibi gastrointestinal şikayetlerle başvuran hastaların ayırıcı tanısında MIS-C akılda tutulmalıdır. Lishman ve arkadaşları “COVID-19'lu Çocuklarda Multisistem Inflamatuvar Sendromda Akut Apandisit" olgu raporunu yayınlamışlardır. Bu yayında akut apandisit ile COVID-19 ve MIS-C arasında bir bağlant olup olmadığı vurgulanmıştır (13).

Kardiyak etkilenim olguların çoğunluğunda izlenmektedir. Godfred-Cato ve arkadaşları takiplerinde $\% 60$ olgunun inotrop desteği ve sıvı resüsitasyonu ihtiyacı olduğunu belirtmişler; Radia ve arkadaşları da olguların en sık kardiyak tutulumla seyrettiğini ve \%77 olguda kardiyovasküler destek (inotrop ve sıvı desteği) gerektiğini raporlamışlardır $(12,14)$. Bizim olgumuzda da kardiyak tutulum [triküspit yetmezliği (hafif-orta) ve mitral yetmezliği (hafif)] izlenmiş olup, hipotansif seyretmesi nedeniyle noradrenalin ve milrinon desteği almıştır. Bu bağlamda MIS-C olgularında erken kardiyak değerlendirme önemlidir.

Laboratuvar izleminde inflamatuvar belirteçlerde artş izlenmektedir. Radia ve arkadaşları olguların \%50'sinde lenfopeni, \%94'ünde CRP artışı saptamışlardır (12).

Hiperinflamatuvar sürecin gerilemesine yönelik tedavi algoritmasında IVIG ve kortikosteroid ile beraber antiviral ve antibiyotik tedaviler ön plana çıkmaktayken, ekstrakorporeal tedavi yöntemlerine çok değinilmemiş ve uygulanmamıştır. Erişkin çalışmalarında, inflamatuvar sitokinlerin plazmadan temizlenmesi ve endotel membran stabilitesinin sağlanmasında TPD'nin etkinliğine değinilmektedir (15). Özellikle yoğun bakım intiyacı olan MIS-C olgularında IVIG ve TPD tedavi kombinasyonunun klinik iyileşme ve inflamatuvar belirteçlerde belirgin gerilemede etkin olabileceği düşünülmektedir.

Bizim hastamızda da ilk başvurusunda lenfositopeni, trombositopeni, CRP yüksekliği saptanmış olup; takibinde ferritin ve D-dimer değerlerinde artş, transaminaz yüksekliği izlenmiştir. TPD ikinci seansı sonrasında inotrop ve noninvaziv oksijen intiyacı ortadan kalkmış, inflamatuvar belirteçlerde belirgin gerileme görülmüştür. Olgumuzda hastalık başlangıç ve tedavi sürecinde inflamatuvar belirteçlerden CRP, ferritin ve D-dimer değerlerindeki değişim Şekil 2, Şekil 3 ve Şekil 4'te gösterilmiştir.

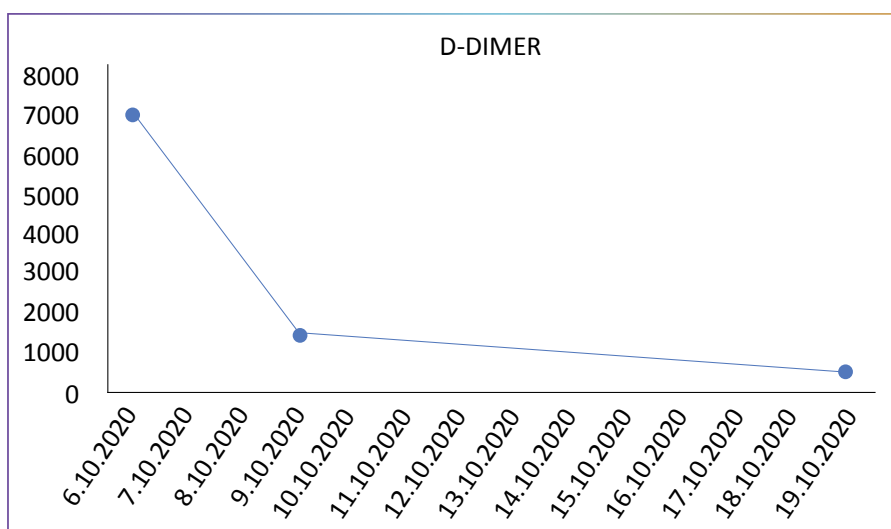

Şekil 3. Terapötik plazma değişimi (TPD) öncesi ve sonrası D-dimer düzeyi takibi.

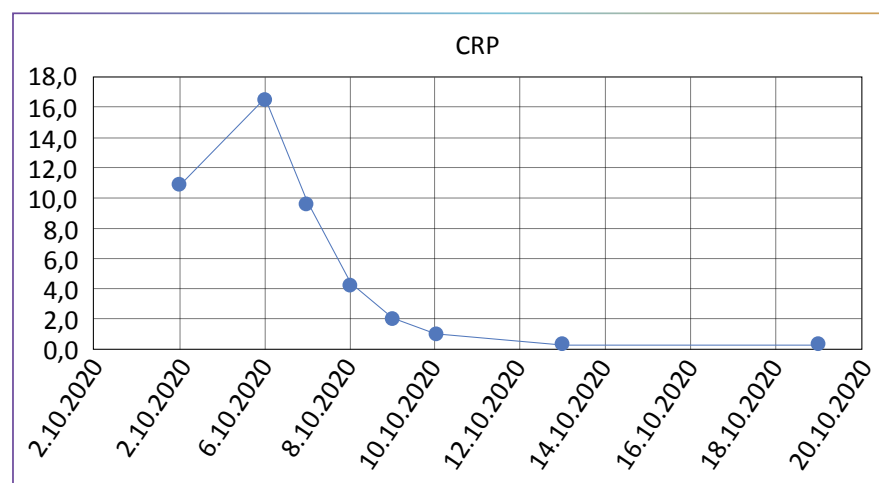

Şekil 4. Terapötik plazma değişimi (TPD) öncesi ve sonrası C-reaktif protein (CRP) düzeyi takibi.

\section{SONUÇ}

COVID-19 ilişkili MIS-C'nin sağlıklı çocuklarda ve ergenlerde ciddi ve hayat tehdit eden hastalığa yol açabileceği literatürde gösterilmiştir. COVID-19'un klinik bulgularının anlaşılmaya çalışıldığı pandemi sürecinde MIS-C'nin geniş bir klinik spektrum gösterdiği ve farklı klinik sistem patolojileriyle (apandisit, perforasyon gibi) hastaların başvuracağı ayırıcı tanıda akılda tutulmalıdır.

Sonuç olarak, özellikle yoğun bakım intiyacı olan MIS-C olgularında IVIG ve TPD tedavi kombinasyonunun kullanılmasının hayat kurtarıcı bir seçenek olabileceği görülmektedir.

Hasta Onamı: Olgu sunumu ve beraberindeki görüntülerin yayınlanması için hastanın ailesinden yazılı bilgilendirilmiş onam alındı.

Çıkar Çatışması: Yazarlar çıkar çatışması bildirmemişlerdir.

Mali Destek: Yazarlar bu çalışma için mali destek almadıklarını beyan etmişlerdir.

Yazarlık Katkıları: Fikir - B.S.; Tasarım - G.A.; Denetmele - C.H.A.; Kaynaklar - E.S.; Malzemeler - D.Ç.; Veri Toplama ve / veya Işleme - S.E.; Analiz ve/veya Yorum - M.O.K.T.; Literatür Taraması - M.O.K.T.; Yazıyı Yazan - M.O.K.T.; Eleştirel İnceleme - C.H.A.

Informed Consent: Written informed consent was obtained from the patient for the publication of the case report and the accompanying images. 
Conflict of Interest: No conflict of interest was declared by the authors.

Financial Disclosure: The authors declared that this study has received no financial support.

Authorship Contributions: Concept - B.S.; Design - G.A.; Supervision C.H.A.; Fundings - E.S.; Materials - D.C..; Veri Toplanması ve/veya İşlemesi-S.E.; Analysis and/or interpretation - M.O.K.T.; Literature review - M.O.K.T.; Writing - M.O.K.T.; Critical review - C.H.A.

\section{KAYNAKLAR}

1. Lu X, Zhang L, Du H, Zhang J, Li YY, Qu J, et al; Chinese Pediatric Novel Coronavirus Study Team. SARS-CoV-2 Infection in Children. N Engl J Med 2020;382:1663-665.

2. Guan WJ, Ni ZY, Hu Y, Liang WH, Ou CQ, He JX, et al; China Medical Treatment Expert Group for Covid-19. Clinical Characteristics of Coronavirus Disease 2019 in China. N Engl J Med 2020;382:1708-720.

3. Center for Disease Control and Prevention, Center for Preparedness and Response: Multisystem Inflammatory Syndrome in Children (MIS-C) Associated with Coronavirus.Disease 2019 (COVID-19), Clinician Outreach and Communication (COCA) Webinar.

4. Multisystem Inflammatory Syndrome in Children (MIS-C) Associated with Coronavirus Disease 2019 (COVID-19). Centers for Disease Control and Prevention (CDC) Health Advisory CDCHAN-00432. Available at: https://www.cdc.gov/mis-c/ Accessed: 30 Dec 2020

5. T.C. Sağ ık Bakanlığı COVID-19 (SARS-CoV-2 enfeksiyonu) çocuk hasta yönetimi ve tedavi rehberi.

6. Lee PY, Day-Lewis M, Henderson LA, Friedman KG, Lo J, Roberts $\mathrm{JE}$, et al. Distinct clinical and immunological features of SARS-CoV2-induced multisystem inflammatory syndrome in children. J Clin Invest 2020;130:5942-950.

7. Sperotto F, Friedman KG, Son MBF, VanderPluym CJ, Newburger JW, Dionne A. Cardiac manifestations in SARS-CoV-2-associated multisystem inflammatory syndrome in children: a comprehensive review and proposed clinical approach. Eur J Pediatr 2020:1-16.

8. Dufort EM, Koumans EH, Chow EJ, Rosenthal EM, Muse A, Rowlands J, et al; New York State and Centers for Disease Control and Prevention Multisystem Inflammatory Syndrome in Children Investigation Team. Multisystem Inflammatory Syndrome in Children in New York State. N Engl J Med 2020;383:347-58.

9. Whittaker E, Bamford A, Kenny J, Kaforou M, Jones CE, Shah P, et al; PIMS-TS Study Group and EUCLIDS and PERFORM Consortia. Clinical Characteristics of 58 Children With a Pediatric Inflammatory Multisystem Syndrome Temporally Associated With SARS-CoV-2. JAMA 2020;324:259-69.

10. Ahmed M, Advani S, Moreira A, Zoretic S, Martinez J, Chorath K, et al. Multisystem inflammatory syndrome in children: A systematic review. EClinicalMedicine 2020;26:100527.

11. Belhadjer Z, Méot M, Bajolle F, Khraiche D, Legendre A, Abakka S, et al. Acute Heart Failure in Multisystem Inflammatory Syndrome in Children in the Context of Global SARS-CoV-2 Pandemic. Circulation 2020;142:429-36.

12. Radia T, Williams N, Agrawal P, Harman K, Weale J, Cook J, et al. Multi-system inflammatory syndrome in children \& adolescents (MIS-C): A systematic review of clinical features and presentation. Pediatr Respir Rev 2020:S1526-054230117-2.

13. Lishman J, Kohler C, de Vos C, van der Zalm MM, Itana J, Redfern A, et al. Acute Appendicitis in Multisystem Inflammatory Syndrome in Children With COVID-19. Pediatr Infect Dis J 2020;39:e472-73.

14. Godfred-Cato S, Bryant B, Leung J, Oster ME, Conklin L, Abrams J, et al; California MIS-C Response Team. COVID-19-Associated Multisystem Inflammatory Syndrome in Children - United States, March-July 2020. MMWR Morb Mortal Wkly Rep 2020;69:1074-080.

15. Keith P, Day M, Perkins L, Moyer L, Hewitt K, Wells A. A novel treatment approach to the novel coronavirus: an argument for the use of therapeutic plasma exchange for fulminant COVID-19. Crit Care 2020;24:128. 